\title{
BMJ Open Impact of price and non-price policies on household cigarette consumption and nutrient intake in smoking- tolerant Indonesia
}

\author{
Triasih Djutaharta (D , , ${ }^{1,2}$ Nachrowi Djalal Nachrowi, ${ }^{1}$ Aris Ananta, ${ }^{1,3}$ \\ Drajat Martianto ${ }^{4}$
}

To cite: Djutaharta T, Nachrowi ND, Ananta A, et al. Impact of price and nonprice policies on household cigarette consumption and nutrient intake in smokingtolerant Indonesia. BMJ Open 2021;11:e039211. doi:10.1136/ bmjopen-2020-039211

- Prepublication history and additional material for this paper are available online. To view these files, please visit the journal online (http://dx.doi org/10.1136/bmjopen-2020039211).

Received 08 April 2020

Revised 06 December 2020

Accepted 15 December 2020

Check for updates

(C) Author(s) (or their employer(s)) 2021. Re-use permitted under CC BY-NC. No commercial re-use. See rights and permissions. Published by BMJ.

${ }^{1}$ Faculty of Economics and Business, Universitas Indonesia, Depok, Jawa Barat, Indonesia

${ }^{2}$ Lembaga Demografi, Faculty of Economics and Business, Universitas Indonesia, Depok, Jawa Barat, Indonesia

${ }^{3}$ Centre for Advanced Research, Universiti Brunei Darussalam, Gadong, Brunei-Muara, Brunei Darussalam

${ }^{4}$ Community Nutrition, Faculty of Human Ecology, IPB University, Kampus Darmaga, Bogor, Jawa Barat, Indonesia

Correspondence to Nachrowi Djalal Nachrowi; nachrowi@ui.ac.id

\section{ABSTRACT}

Objective To examine the impact of cigarette price and smoking environment on allocation of household expenditure and its implication on nutrition consumption. Design A cross-sectional study was conducted using the 2014 National Socioeconomic Survey (SUSENAS), the 2014 Village Potential Survey (PODES) and the 2013 Basic National Health Survey (RISKESDAS). SUSENAS and PODES data were collected by the Central Bureau of Statistics. RISKESDAS was conducted by National Institute of Health Research and Development (Balitbangkes), Indonesian Ministry of Health (MOH).

Setting and participants The sample covered all districts in Indonesia; with sample size of 285400 households. These households are grouped into low, medium and high smoking prevalence districts.

Primary and secondary outcome measures The impact of cigarette price and smoking environment on household consumption of cigarette, share of eight food groups, as well as calorie and protein intake.

Result $1 \%$ increase in cigarette price will increase the cigarette budget share by 0.0737 points and reduce the budget share for eggs/milk, prepared food, staple food, nuts, fish/meat and fruit, from 0.0200 points (eggs/milk) up to 0.0033 points (fruit). Reallocation of household expenditure brings changes in food composition, resulting in declining calorie and protein intake. A $1 \%$ cigarette price increase reduces calorie and protein intake as much as $0.0885 \%$ and $0.1052 \%$, respectively. On the other hand, existence of smoke-free areas and low smoking prevalence areas reduces the household budget for cigarettes.

Conclusion A pricing policy must be accompanied by non-pricing policies to reduce cigarette budget share.

\section{INTRODUCTION}

\section{Research question}

The central question is to choose between price policy and non-price policy to reduce cigarette smoking. Furthermore, is it possible that the price policy results in undesirable impact on nutrient intake?

\section{Background}

Twenty years ago, Indonesia had a tobacco endemic, ${ }^{1}$ which has continued until the
Strengths and limitations of this study

- The strength of the study is its effort to compare the impact of pricing policy and non-pricing policy on household cigarette consumption and nutrient intakes through household food consumption.

- There are four limitations of this study. The first is that it has not explained the mechanism of the influence of smoking social environment and smoking prevalence on household cigarette budget share. Further studies should find out this mechanism.

- The second is that it has not considered the substitution between food and non-food consumption. Non-food consumption is here assumed not to affect nutrient intake.

- The third is the use of district as the community variable of smoking environment. The ideal unit is village, but there is no information at village level. However, the use of district is already better than a similar study in Japan, which used prefecture, wider than district.

- The fourth is that the main data (National Socioeconomic Survey) were based on self-reported information by the respondents, though the study has utilised consumption expenditure as a proxy of total household income.

present. The smoking prevalence and number of smokers in Indonesia are the highest in Association of Southeast Asian Nations (ASEAN) region. The smoking prevalence among men is $67.4 \%$ and the number of smokers is $50 \%$ of total smokers in ASEAN (65.2 million). ${ }^{2}$ The prevalence of secondhand smokers is also very high, especially in restaurants, with more than $80 \%$ of visitors exposed to it. ${ }^{3}$ At the household level, the 2014 National Socioeconomic Survey finds cigarette consumption at 6 out of every 10 households.

Reducing cigarette consumption with a price policy was expected to be an effective policy in Indonesia. Therefore, Ministry of 
Finance, Republic of Indonesia regularly raises tobacco excise and revises the minimum retail price of cigarette. However, previous studies found that increase in cigarette price reduced cigarette consumption but the reduction is small. This is because the demand for cigarette is inelastic. The elasticity from a single equation is found to be between -0.15 and $-0.90 .{ }^{4-6}$ Tobacco studies in Indonesia showed price elasticity ranges from -0.3 to $-0.76 .{ }^{17-9}$

This inelastic demand may be because smoking is part of life among most men in Indonesia. Smoking is perceived as a masculinity symbol especially for young population. It is sometimes a social obligation to serve cigarette to welcome guests, ${ }^{10}{ }^{11}$ and to tip people for their services by saying that the tip is money for buying cigarette (uang untuk rokok). ${ }^{10}$ Furthermore, the Nahdatul Ulama, the largest Islamic organisation in Indonesia, is not against smoking. ${ }^{12}$ Peer group also influences smoking behaviour in Indonesia ${ }^{11} 13$

Therefore, smoking as a social norm ${ }^{12}$ may have hampered the efforts in reducing cigarette consumption in Indonesia. Men may not reduce cigarette consumption much, but they reduce other consumptions, including food expenditure and then nutrient intake.

As a result, non-price tobacco control policy is also implemented in Indonesia. The government issued Health Law No 36 in 2009, determining some areas to be smoke-free areas (SFAs). The law states that governments at lower levels must establish SFAs in their regions. There are seven areas for SFA: health service facilities, teaching and learning places, places for children playground, places of worship, public transportation, working places, public places and other designated places. Afterwards, some local governments created their own SFAs.

Nevertheless, there has been no empirical study to evaluate the impact of SFAs on household cigarette consumption expenditure. Furthermore, there has neither empirical study which evaluates price and non-price policies simultaneously in Indonesia. Therefore, the first novelty of this study is its effort to evaluate the impact of non-price policy on both household cigarette consumption and nutrient intake. The second novelty is its examination on impact of price policy on both cigarette consumption and household nutrient intake. The third novelty is the use of Almost Ideal Demand System model to examine impact of price and non-price variables.

\section{Objectives}

This study fills in the mentioned absence of empirical studies by examining the impact of price and smoking environment on reallocation of household expenditure as well as its implications on nutrition intake.

\section{METHOD}

\section{Data availability}

This is a cross-sectional study with the national coverage, having household as the unit of analysis. The main data set is 2014 Indonesia National Socioeconomic Survey
(SUSENAS) conducted by Central Bureau of Statistics (CBS) in 2014. Another data set is the 2014 Village Potential Survey (PODES), also conducted by CBS. These two data sets can be accessed through website Silastik.bps.go. id. This paper also uses some published Basic National Health Survey (RISKESDAS) data from Ministry of Health (MOH) Republic of Indonesia ${ }^{14}$ and a report. ${ }^{15}$

\section{Study design and setting}

SUSENAS collects the data on expenditure and quantity of 215 types of food, including tobacco products and household characteristics. Each type of food commodity is then converted into calorie and protein intake, by referring to the list of foods ingredient composition published by $\mathrm{MOH}$. The SUSENAS is an annual survey, which has a total sample of around 285400 households scattered across 34 provinces and 497 districts. Enumerators collected the information through face-to-face interview in respondents' residences.

Smoking environment is measured at the district level. There are two indicators: smoking prevalence and existence of SFA regulation. The data for smoking prevalence are obtained from the publication of the 2013 RISKESDAS. ${ }^{14}$ This survey is conducted by $\mathrm{MOH}$ every $3-5$ years. There are 151 districts with smoking regulation. ${ }^{15}$.

PODES collects information of villages' characteristics, such as transportation, infrastructure and the existence of food service provider infrastructure. The PODES was conducted through direct interview by CBS officers along with the village heads. ${ }^{16}$ The PODES is used to estimate value of unit deviation to obtain the corrected unit value (UV) (price).

\section{Statistical analysis}

This study uses Deaton and Muellbauer's framework 'Almost Ideal Demand System (AIDS)' model. The AIDS model has several advantages, such as: (i) accommodating several properties in the demand function, so that the model can well capture household expenditure behaviour; (ii) using a type of general utility function, avoiding the possibility of incorrect specifications in the model; (iii) accommodating a form of linear function, allowing an easier estimation; (iv) including control variables (in addition to price and income variables) and new variables into the demand model ${ }^{17}$ and using demographic variables as control variables to accommodate different household needs. ${ }^{18}$

Other people's preferences affect the demand function through constants and not through price parameters. ${ }^{190}$ Therefore, this paper includes 'smoking environment', indicated by smoking prevalence among population aged 10 years old and above; and a dummy variable in the form of SFA at the district level. It also includes demographic and social environmental factors in the model as the constant on the AIDS equation.

This study also considers the possibility of selectivity bias because of excluding households who do not consume a certain commodity. To manage this possibility the study 
includes inverse Mills ratio (imr) in each of the demand equations as a proxy of the missing important independent variable. ${ }^{21}$ The $i m r$ is estimated from the results of the probit model for commodities consumed by the households (see online supplemental appendix 1). The AIDS model equation is as follows:

$$
\begin{aligned}
\mathrm{w}_{\mathrm{k}} & =\delta_{k}+\sum_{j=1}^{9} \gamma_{k j} \log \mathrm{P}_{\mathrm{kj}}+\beta_{\mathrm{k}} \log \left(\frac{\mathrm{X}}{\mathrm{P}}\right) \\
& +\theta_{k} \operatorname{Prev}_{\mathrm{kab}}+\mu_{\mathrm{k}} \operatorname{Law}_{\mathrm{kab}}+\theta_{\mathrm{kr}} \sum_{\mathrm{r}=1}^{4} \mathrm{HH}_{\mathrm{r}}+\mathrm{imr}_{\mathrm{k}}+\epsilon_{\mathrm{i}}
\end{aligned}
$$

$\mathrm{W}_{\mathrm{k}}$ is the budget share of household on commodity $k$ of total expenditure on nine commodities,

$\mathrm{k}=1,2,3, \ldots, 9$, where 1 =cigarette, $2=$ staple food, $3=$ vegetables, $4=$ fruit, $5=$ fish $/$ meat, $6=$ eggs $/ \mathrm{milk}, 7=$ nuts, $8=$ prepared food, $9=$ other foods.

Explanatory variables are prices of nine commodities, total household expenditure, household characteristics, a dummy variable for SFA at district level and smoking prevalence at district level. Prices are measured at their corrected values.

$\ln p_{j}=$ corrected UV (price) $\mathrm{j}$ (in $\ln$ ), where $\mathrm{j}=1,2,3, \ldots .9$. Corrected UV is calculated by (i) estimating UV deviation (DUV) of household by UV mean, (ii) carrying out Ordinary Least Squares (OLS) DUV regression of household characteristics and transportation accessibility in regional level, (iii) obtaining corrected UV by omitting UV in household level with the predicted DUV. The result of OLS DUV estimation is presented in online supplemental appendix 2.

$\ln \left(\frac{X}{P}\right)$ is the total real household expenditure (in $\ln$ ), with $\mathrm{X}$ as total expenditure of nine commodities and $\mathrm{P}$ as price index. Household expenditure is used as a proxy of income because self-reported information on income is under reported. ${ }^{22}$ Arbrianty ${ }^{23}$ uses household expenditure as an income proxy for estimating the poor household category. CBS neither publishes information on income for the public. Therefore, household expenditure better measures households' economic welfare. ${ }^{24}$

$\mathrm{P}$, price index, is calculated using the stone $\mathrm{i}: \mathrm{P}=\sum_{\mathrm{k}=1}^{9} \mathrm{w}_{\mathrm{k}} \mathrm{p}_{\mathrm{k}}$

$\operatorname{Prev}_{\mathrm{kab}}$ is the smoking prevalence in the district (in percentages). The use of the district is better (smaller) compared with Yamamura's study using prefecture. ${ }^{25}$

$\mathrm{Law}_{\mathrm{kab}}$ is the regulations of district on non-smoking areas (dummy of SFA variable).

$\sum_{1}^{3} \mathrm{HH}_{\mathrm{r}} \mathrm{is}$ the households' characteristics; there are three groups: (i) dummy of household living in urban area, (ii) total number of population according to age group and gender and (iii) characteristics of household heads: dummy of sex and years of schooling.

Impact of changes in cigarette prices $(\ln )$ on the share of spending of the nine commodities consumed by the households:

Where $P_{1}$ refers to price of cigarette, and $w_{1}$ to cigarette budget share. $w_{j}$ refers to a certain commodity budget share, where $\mathrm{j}=1,2,3, \ldots . .9$.

$\gamma_{j}$ indicates direct effect and $\beta_{\mathrm{j}} \mathrm{w}_{1}$ indicates indirect effect.

Information on nutrition intake was not collected in the household surveys. Therefore, the impact on nutrient is estimated indirectly through the impact on food consumption, as the survey collects data on expenditure and quantity on the commodity consumed. Indirect nutritional elasticity estimation has been conducted ${ }^{26-29}$ and the calculation of nutritional elasticity on commodity $\mathrm{k}\left(\pi_{\mathrm{kj}}\right)$ is a weighted average of own and cross price elasticity: ${ }^{26} 2829$

where $\phi_{k}$ is the total nutrition $k$, calculated from $\phi_{\mathrm{k}}=\sum_{\mathrm{i}} \mathrm{n}_{\mathrm{kj}}$

$\mathrm{n}_{\mathrm{kj}}$ is nutrition $k$ from commodity $j$,

$\mathrm{e}_{\mathrm{ij}}$ is percentage change in quantity of food consumed because of percentage change in price of cigarette (quantity price elasticity).

The regression is run with five equations of AIDS. The first three are related to three categories of smoking prevalence districts and the last two are districts with SFA regulation and districts without SFA regulation. The first three categories are households in low smoking prevalence districts (with prevalence rate between $6.63 \%$ and $27.22 \%$, comprising 95144 households), medium smoking prevalence districts (with prevalence rate between $27.24 \%$ and $30.67 \%$, consisting of 94864 households) and high smoking prevalence districts (with prevalence rate between $30.68 \%$ and $44.08 \%$, covering 94864 households). Readers interested in detailed results of the AIDS regression by smoking prevalence and SFA district can contact the authors.

\section{Patient and public involvement}

Neither patients nor any member of public was involved in this study.

\section{RESULTS}

\section{Descriptive analysis}

There were 285400 households. Cigarette consumption or cigarette expenditure was observed in $60.9 \%$ of the households. The number of households with staple food, vegetables and other food consumption is more than $95 \%$ for each category (table 1). Cigarette expenditure is about 1.5 times that of vegetables, 2.5 times of fruit, 2.2 times of eggs/milk and 5.5 times of nut. The proportion of cigarette expenditure to total food (including cigarette) is $11.8 \%$ (table 2 ).

Households living in high smoking prevalence districts have a higher percentage of smoking household, higher cigarette expenditure and budget share (tables 1 and 2). Interestingly, percentage of smoking households is slightly lower than in non smoking-free districts. This result may indicate that the regulation may not have been 
Open access

Table 1 Household commodity consumption (percentage) by smoking prevalence and smoke-free areas

\begin{tabular}{|c|c|c|c|c|c|c|}
\hline \multirow[b]{2}{*}{ Commodities } & \multicolumn{3}{|c|}{ Smoking prevalence districts } & \multicolumn{2}{|c|}{ SFA District } & \multirow[b]{2}{*}{ All } \\
\hline & Low & Medium & High & No & Yes & \\
\hline Cigarette & 54.5 & 62.1 & 66.2 & 61.3 & 60.2 & 60.9 \\
\hline Staple food & 97.2 & 97.6 & 98.4 & 98.2 & 96.5 & 97.7 \\
\hline Vegetable & 94.7 & 95.4 & 96.7 & 96.7 & 92.9 & 95.6 \\
\hline Fruit & 75.6 & 77.8 & 75.6 & 74.6 & 80.7 & 76.3 \\
\hline Fish/meat & 87.0 & 90.5 & 92.3 & 90.4 & 88.9 & 89.9 \\
\hline Milk/egg & 75.4 & 80.1 & 78.4 & 75.4 & 84.2 & 78.0 \\
\hline Nuts & 66.2 & 72.8 & 73.8 & 68.1 & 77.8 & 70.9 \\
\hline Prepared food & 86.8 & 93.0 & 90.9 & 87.9 & 96.1 & 90.2 \\
\hline Other food & 97.9 & 98.3 & 98.7 & 98.7 & 97.5 & 98.3 \\
\hline
\end{tabular}

Source: by the authors.

Note: SFA, smoke-free areas.

Table 2 Budget share by smoking prevalence districts

Smoking prevalence districts

\begin{tabular}{|c|c|c|c|c|c|c|c|c|}
\hline \multirow[b]{2}{*}{ Budget share (\%) } & \multicolumn{2}{|l|}{ Low } & \multicolumn{2}{|l|}{ Medium } & \multicolumn{2}{|l|}{ High } & \multicolumn{2}{|l|}{ All } \\
\hline & Share & SD & Share & SD & Share & SD & Share & SD \\
\hline Cigarette & 10.0 & 11.7 & 12.1 & 12.2 & 13.3 & 12.5 & 11.8 & 12.2 \\
\hline Staple food & 22.8 & 14.9 & 20.6 & 11.3 & 23.3 & 11.6 & 22.2 & 12.8 \\
\hline Vegetable & 9.8 & 6.4 & 10.0 & 5.7 & 10.4 & 5.7 & 10.1 & 5.9 \\
\hline Fruit & 4.9 & 5.1 & 5.0 & 4.9 & 4.7 & 5.0 & 4.9 & 5.0 \\
\hline Fish/meat & 14.4 & 10.5 & 14.7 & 9.8 & 13.7 & 9.5 & 14.3 & 9.9 \\
\hline Milk/egg & 5.1 & 6.5 & 5.4 & 6.5 & 4.8 & 5.9 & 5.1 & 6.3 \\
\hline Nuts & 2.7 & 3.2 & 2.7 & 3.0 & 2.8 & 3.0 & 2.7 & 3.1 \\
\hline Prepared food & 21.6 & 20.0 & 20.8 & 18.3 & 17.9 & 16.4 & 20.1 & 18.3 \\
\hline Other food & 8.6 & 4.8 & 8.7 & 4.7 & 9.1 & 4.8 & 8.8 & 4.8 \\
\hline Total & 100.0 & & 100.0 & & 100.0 & & 100.0 & \\
\hline $\begin{array}{l}\text { Expenditure } \\
\text { (IDR/week) }\end{array}$ & Expend & SD & Expend. & SD & Expend. & SD & Expend. & SD \\
\hline Cigarette & 36583 & 52189 & 45195 & 56812 & 46078 & 54979 & 42618 & 54862 \\
\hline Staple food & 63585 & 50916 & 60100 & 37154 & 62706 & 37172 & 62128 & 42274 \\
\hline Vegetable & 28430 & 22447 & 30225 & 20699 & 29074 & 20516 & 29244 & 21252 \\
\hline Fruit & 17299 & 24152 & 18542 & 24833 & 16096 & 23198 & 17314 & 24092 \\
\hline Fish/meat & 49091 & 52832 & 52482 & 53640 & 45913 & 49722 & 49168 & 52164 \\
\hline Milk/egg & 19763 & 38006 & 21414 & 39323 & 17437 & 34677 & 19542 & 37426 \\
\hline Nuts & 7600 & 9084 & 7909 & 8728 & 7319 & 7865 & 7610 & 8578 \\
\hline Prepared food & 75822 & 97945 & 78916 & 102312 & 60563 & 82698 & 71784 & 95049 \\
\hline Other food & 25487 & 18678 & 26518 & 18115 & 25750 & 18280 & 25919 & 18364 \\
\hline $\begin{array}{l}\text { HH food expenditure } \\
\text { (IDR/week) }\end{array}$ & 323660 & & 341302 & & 310935 & & 325327 & \\
\hline $\begin{array}{l}\text { HH expenditure } \\
\text { (IDR/month) }\end{array}$ & 2963636 & 3298577 & 3088544 & 3486383 & 2601026 & 2465585 & 3123010 & 3123010 \\
\hline
\end{tabular}

Note: Description of variables is referred to online supplemental appendix 3

Source: by the authors

$\mathrm{HH}$, household; IDR, Indonesian rupiah. 
Table 3 Budget share by smoke-free area (SFA districts)

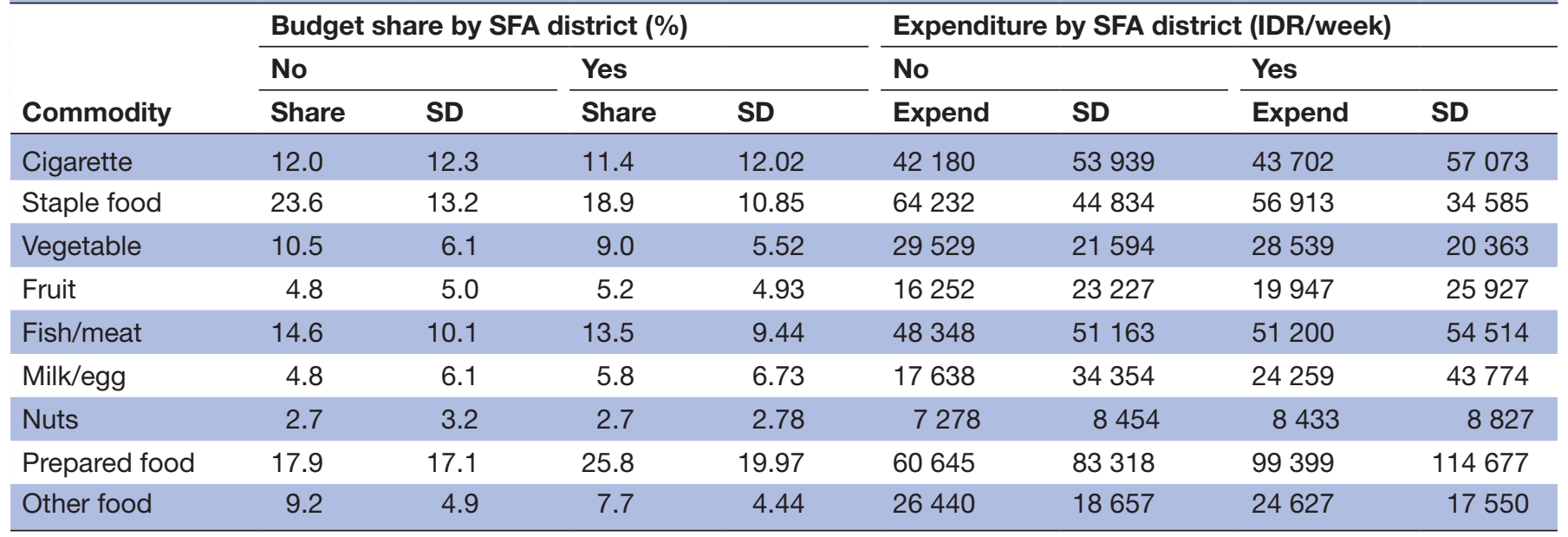

Note: Description of variables is referred to online supplemental appendix 4.

Source: by the authors.

well implemented or it may not have been implemented for a sufficiently long time.

Table 3 shows that households living in smoking-free districts have lower cigarette budget share than those in non-smoking-free districts, with $11.4 \%$ and $12.0 \%$, respectively. The households in smoking-free districts have a much higher share of prepared food, $25.8 \%$ in smokingfree districts compared with $17.9 \%$ in non-smoking-free districts. In absolute term, households in smoking-free districts have a larger amount of household expenditure.

\section{Main results}

Effects of the smoking environment on cigarette budget share

Table 4 shows that higher smoking prevalence increases household cigarette budget share. Reducing the smoking prevalence is associated with smaller household cigarette budget share. An increase in smoking prevalence by one percentage point will raise the cigarette budget share by 0.114 percentage point. At the same time, an increase in smoking prevalence will reduce budget share for all food commodities, except for vegetables. This can be seen from the negative coefficient of smoking prevalence coefficient for all food commodities. It ranges from -0.00266 (staple food) to -0.0000841 (eggs $/ \mathrm{milk}$ ).

The SFA policy has a negative impact on cigarette budget share. Existence of regulation on SFAs is associated with smaller household cigarette consumption. The policy has a significant effect on reducing cigarette budget share. Households living in districts with SFA regulations have a lower cigarette budget share by 0.963 percentage point than the ones who live in districts without SFA. Households in districts with SFA have more expenditure share on prepared food, staple food and egg/milk (table 4). It is possible that the households living in districts with SFA policy reallocate their budget for more prepared food, implying a reduction in budget share for uncooked food, which needs to be cooked before being consumed (table 3).
The cigarette budget share in households with SFA is lower than the share in households living in districts without SFA, regardless the category of smoking prevalence districts. Furthermore, the impact of smoking prevalence districts on the cigarette budget varies depending on the smoking environment. The impact is an increase of 0.00130 point among low smoking prevalence districts; a decrease of 0.00111 point among medium smoking prevalence households and a decrease of 0.000970 point among high smoking prevalence households. Moreover, the impact of smoking prevalence on budget share is very small, regardless of whether the households are in smokefree districts or not. The impact is between 0.00104 point in smoking-free districts and 0.00102 point in nonsmoking-free districts (table 5).

\section{Effect of cigarette price on budget share allocation}

AIDS estimation results show that the price of cigarette has a significant effect on household budget share. Without environmental variables, the coefficient of cigarette price is 0.0770 , and with environmental variables, the coefficient becomes smaller, 0.0733 (table 4). It implies that smoking environment reduces the coefficient of cigarette price, meaning that some of 'price effect' is actually the impact of smoking environment.

Furthermore, the price of cigarette affects its budget share through two mechanisms: directly through cigarette price and indirectly through the real household expenditure. The direct effect of cigarette price is greater than the indirect effect, regardless of the category of smoking prevalence households and district with SFA (tables 6 and 7).

As shown in table 6 , the net impact of an increase of cigarette price by one percentage will increase the budget share of cigarettes (7.37 percentage point), vegetables (1.07 percentage point) and other food (0.02 percentage point). The net impact also reduces the budget share of six food commodities, with a range from 0.186 percentage 


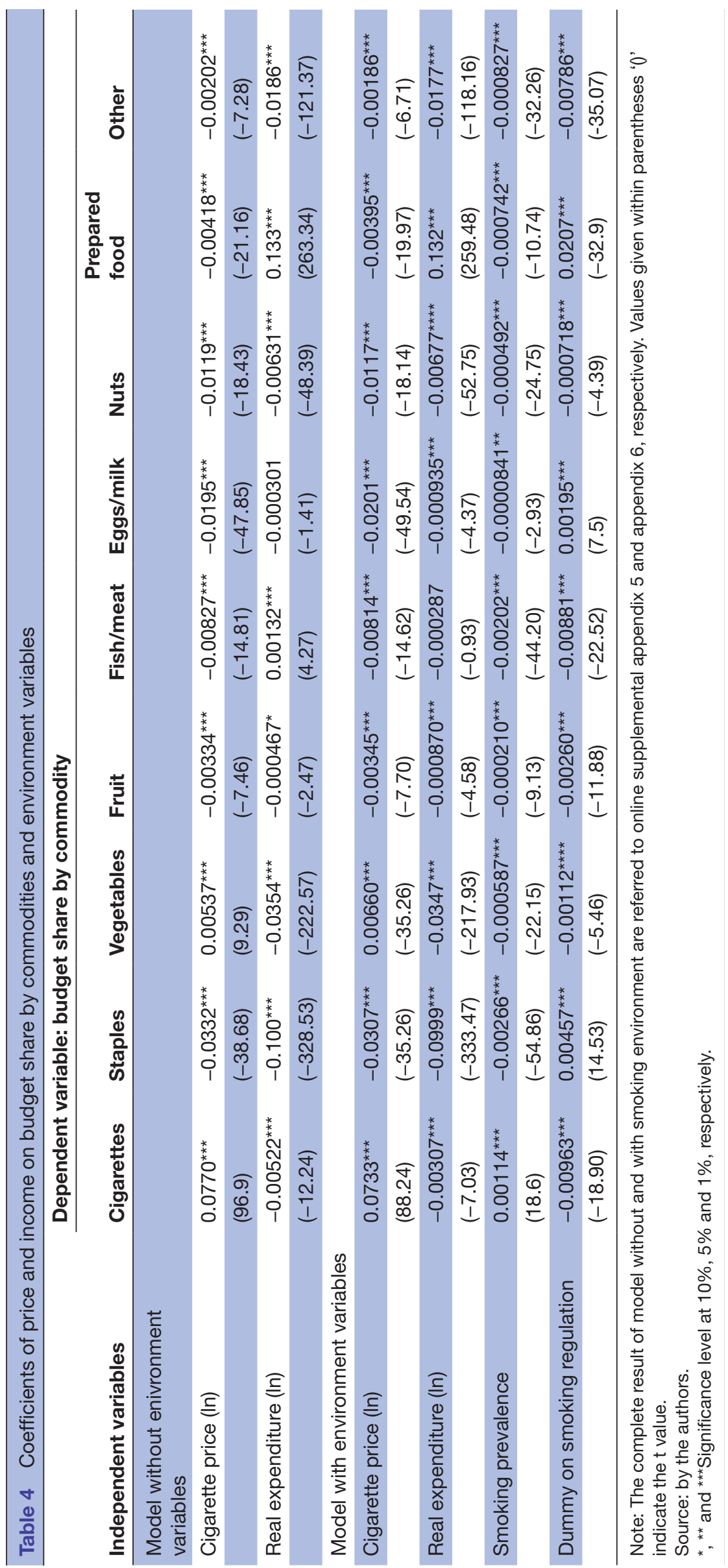




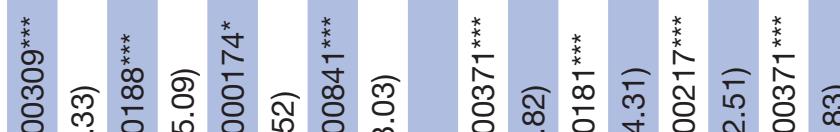

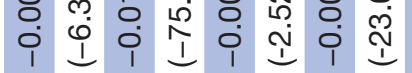

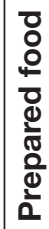

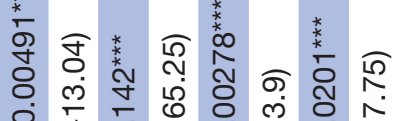

I I

家

$\stackrel{n}{z}$

i 1 i

产

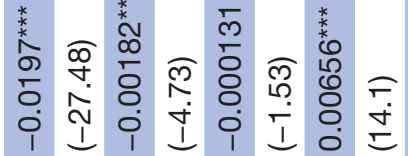

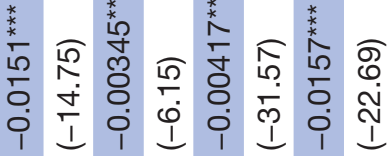

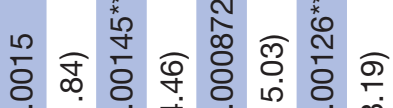

i I i I i I o I

กับ

華

O

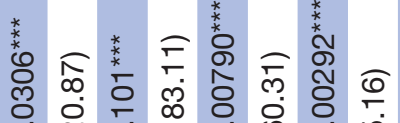

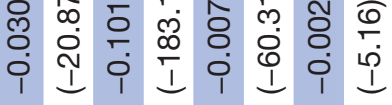

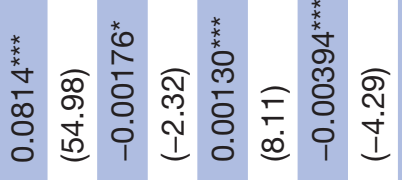

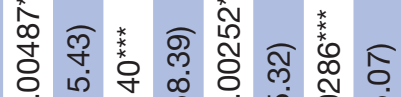

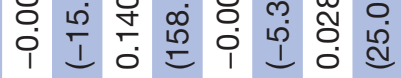

先

ठำ

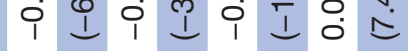

离

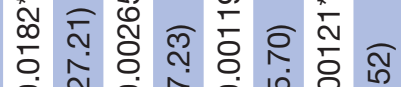

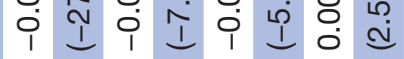

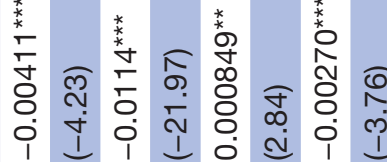

\%

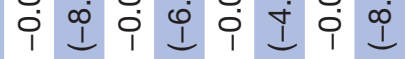

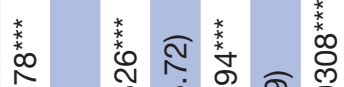

๑

O

*

鹤品

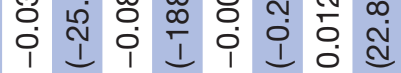

等

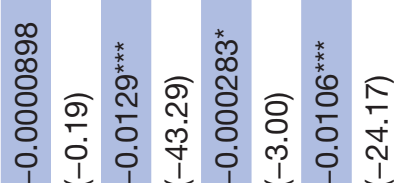

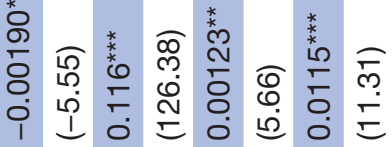

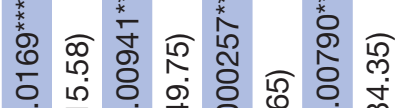

次

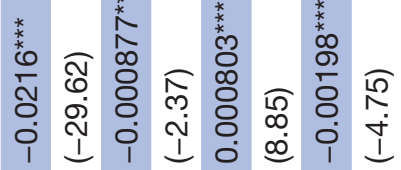

要

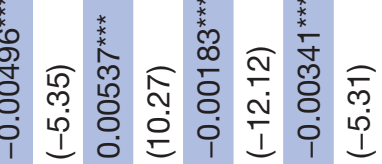

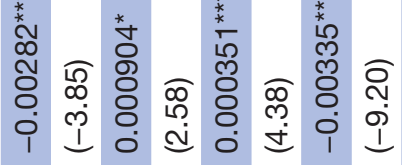

每

๕

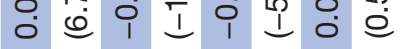

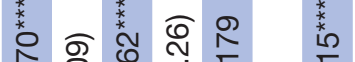

每

1

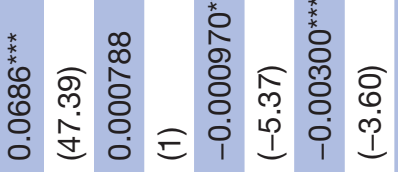

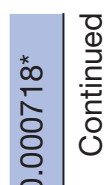

i

$\vec{\circ}$

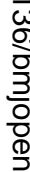

กิ

这

음

$\vec{\infty}$

ֻั

$\stackrel{2}{2}$

Nิ

뭉

产

ㅇํㅇ

음

吾

읔

긍

을

ำ

옥

을

N

Nิ

ऽ

$\stackrel{0}{\mathbb{D}}$

$\stackrel{\infty}{+}$

뭉

京

뭉

ㅇํㅇ 


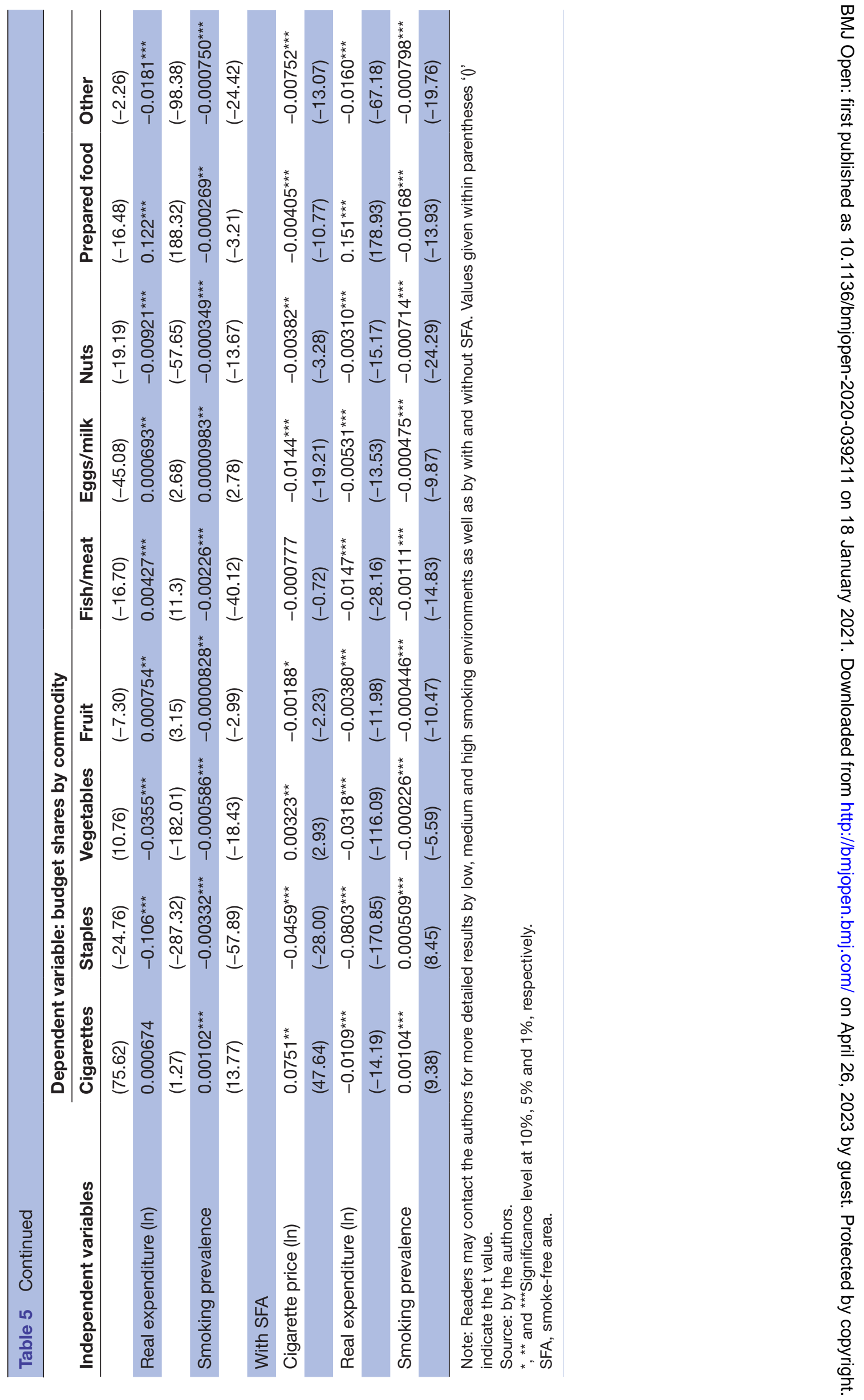



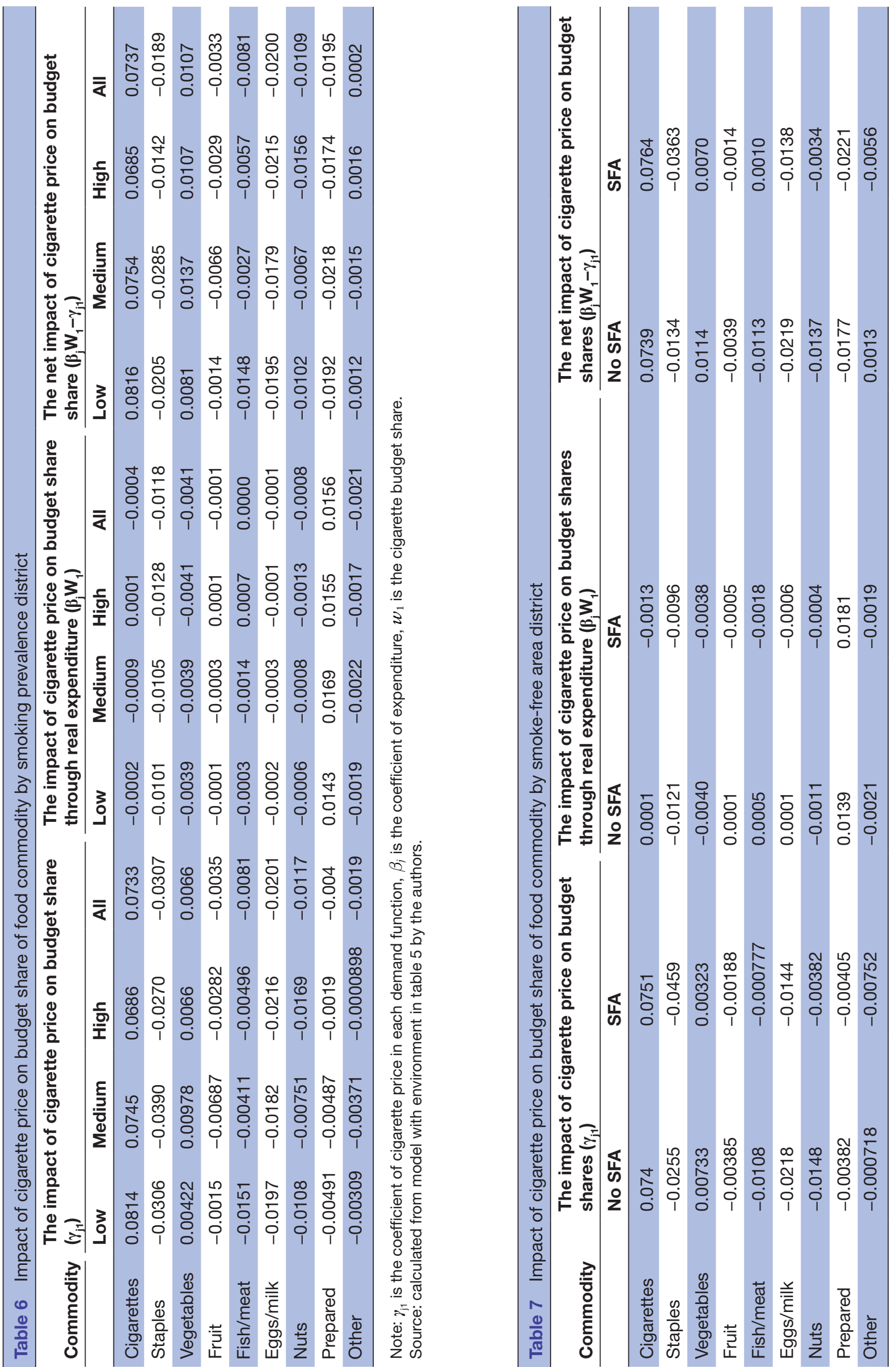

ᄃ

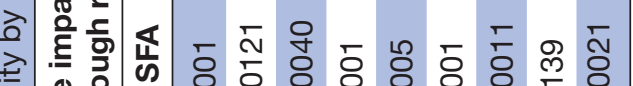

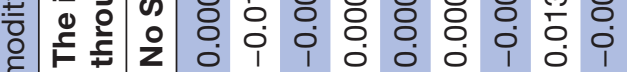

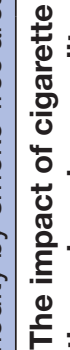


point (other food) to 2.07 percentage point (staple food). Staple food has the biggest impact, because the share of staple food expenditure is the largest. The lowest impact is on egg $/ \mathrm{milk}$, because egg/milk has the least elastic demand function, compared with all commodities. This shows that the increase in cigarette prices will result in reduction of budget share in a number of food groups.

The net impact of cigarette price increase on cigarette budget share is positive, regardless of the categories of smoking prevalence households. Nevertheless, the impact is smaller in higher smoking prevalence households. The impact is 0.0816 point among low smoking prevalence household; 0.0754 point among medium smoking prevalence households and 0.0685 point, among high smoking prevalence households (table 6). Furthermore, table 7 also indicates that the difference of the impact of cigarette price on cigarette budget share among SFA is small, 0.0764 point in smoke-free districts and 0.0739 point in non-smoke-free districts.

\section{The effects of cigarette price on nutrition intake}

The result above shows that the increase on cigarette price will raise cigarette budget share and reduce the budget share of most food commodities, implying a reduction in calorie and protein intake of the households. The price increase by $1 \%$ will reduce intake of calorie by $0.0885 \%$ and protein by $0.1502 \%$ (table 8 ). The decline of the share of calorie and protein in each food category depends on the nutrition share on total nutrition intake (online supplemental appendix 7 and appendix 8) and cross-price elasticity (online supplemental appendix 9). Staple food has the biggest impact on the decline of energy and protein intake by 0.0492 point and 0.0355 point, respectively (table 8 ). The reason for this is that staple food is the main source of energy $(57.88 \%)$ and protein $(41.88 \%)$ in the household.

The calorie and protein elasticities do not differ much by smoking prevalence households. The protein elasticity of cigarette price is weaker among higher smoking prevalence households. The coefficients are -0.1154 to -0.1059 and -0.1034 among low, medium and high smoking prevalence households respectively. Protein elasticity is a little stronger in SFA district -0.1067 than in no SFA -0.0820 . The largest decline in calorie elasticity is seen among medium smoking prevalence households $(-0.1150)$, with high smoking prevalence having smaller decline $(-0.0754)$ than among low smoking prevalence households $(-0.0937)$. Calorie elasticity is stronger in SFA area, -0.1249 , than in without SFA -0.0767 (table 8).

\section{DISCUSSION}

\section{Key results}

The increase in price is expected to reduce the household cigarette budget share. However, the results show that the increase in cigarette price reduces the allocation of the majority food expenditure but increases the budget share for cigarettes. This is in line with a study in the USA which argues that an increase in cigarette tax by US $\$ 1$ will increase the budget share by $0.1 \%{ }^{30}$ As a result, the decrease in food expenditure may lower calorie and protein intake of the households. This result is different from the one in Bangladesh, where household expenditure on tobacco is allocated to food, and therefore the households obtain additional calories between 508 and $924 \mathrm{kcal}$, such that the number of malnutrition can be reduced by $6 \%-9 \%{ }^{31}$

In Indonesia, the price of Marlboro brand, the famous brand, is only US $\$ 1.90$, much lower than the level of cigarette prices that will make youth smokers stop smoking (US\$3.76). ${ }^{3}$ The affordability of and easy access to cigarettes in Indonesia may be the main causes of the high smoking prevalence. During the 2013-2018 period, smoking prevalence of population aged 10 years and over did not show a significant reduction, from $29.3 \%$ to $28.8 \%{ }^{32}{ }^{33}$ It is different from Thailand's experience, where raising cigarette prices, through higher excise tax, was able to make smokers quit smoking and therefore reduce smoking prevalence.

Another result of the paper is that smoking social environment has a positive correlation with the households' cigarette expenditure. This finding is supported by a study showing that smoking prevalence increases the number of participation in smoking and cigarette consumption, ${ }^{34}$ because of social effects on smoking behaviour. ${ }^{35}$ The effects can be manifested in the form of obedience to social norms, social interactions or psychological effect. ${ }^{25}{ }^{36}$ From a social norm perspective, cigarette consumption in Indonesia is seen as modernisation of traditional cultures. ${ }^{11}$ Therefore, a policy on cigarette price alone is not sufficient and has to be accompanied by non-price policies to develop antismoking norms, unless the increase in price is sufficiently high, perhaps as high as $100 \%$ increase.

SFAs policy has a small effect on budget share, because the SFA policy in Indonesia depends on local government at district level and therefore the policy varies among districts. Several small studies show that society and stakeholder agree with SFA policy, but its implementation has often been questionable. ${ }^{37-39}$

\section{Summary}

An increase in the price of cigarette by $1 \%$ will increase the budget share for cigarettes by 0.0737 point and decrease budget share for most food categories. The largest decline in budget share is for eggs/milk $(0.0200$ points), followed by prepared food ( 0.0195 point).

The decline in food consumption will then reduce nutrient intake and protein. A $1 \%$ increase in cigarette price reduces calorie consumption by $0.0885 \%$ and protein consumption by $0.1052 \%$. The large reduction in calories and protein is because of reduction in consumption of staple food, which have the largest share of household calories and protein; that is, $57.9 \%$ and $41.8 \%$, respectively. 


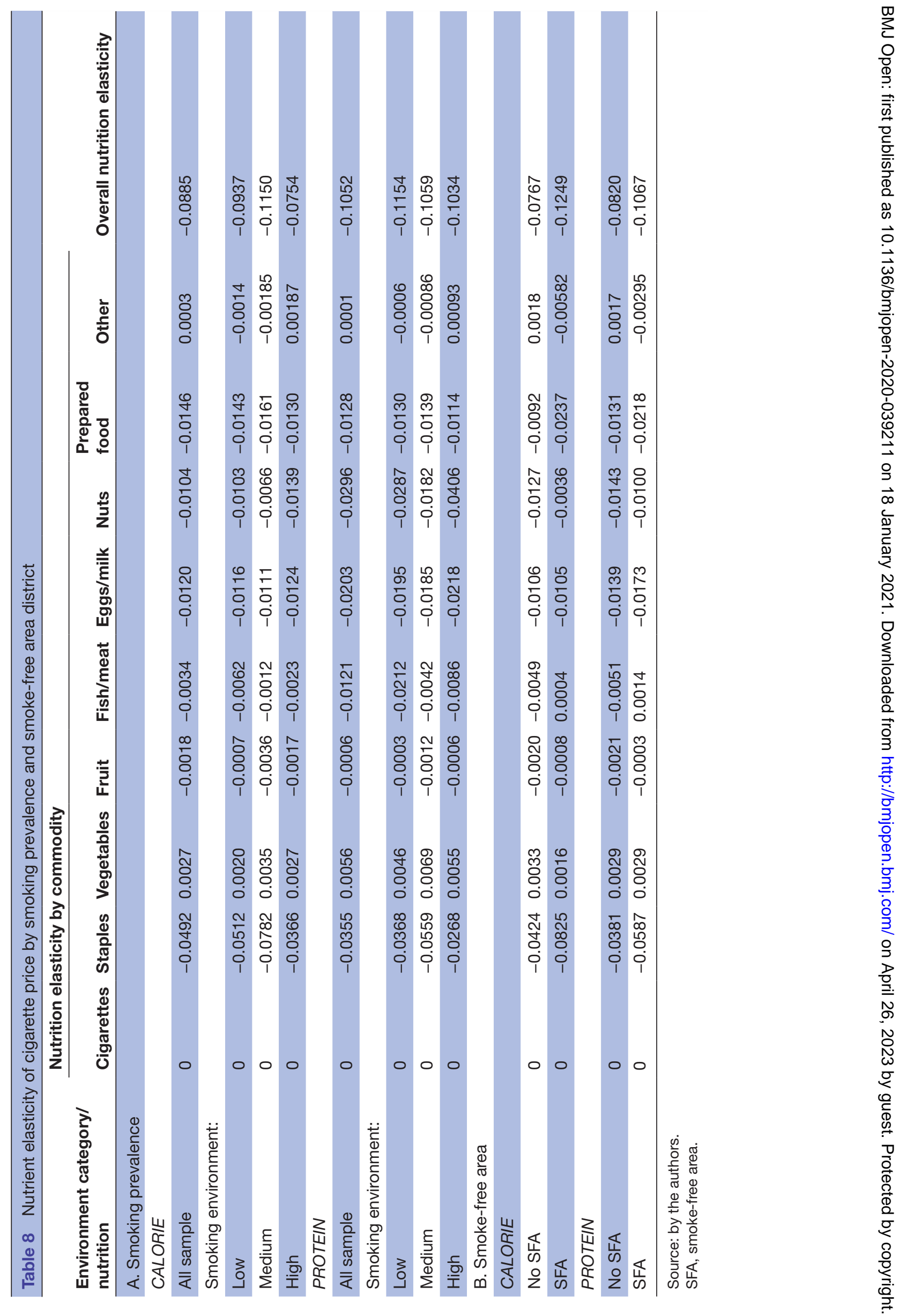


In other words, the cigarette price policy does not reduce household expenditure on cigarettes. Moreover, price policy reallocates household expenditure by reducing the majority of household food expenditure and therefore may also lowering nutrient intake.

On the other hand, reducing smoking environments will be more effective in lowering the budget share for cigarettes. Households in areas with SFA have a lower cigarette budget share. Therefore, non-price policy is more effective in reducing cigarette consumption without reducing nutrient intake.

\section{Recommendation}

Price policy can reduce cigarette, but not much. Therefore, price policy alone may not be sufficient to stop people from smoking. As the demand is inelastic, the government needs to raise the price to a very high level to make the price policy effective in stopping smoking cigarette, perhaps with a least $100 \%$ increase. On the other hand, non-price policies seem to have worked more effectively. Therefore, price policy should be accompanied by non-price policies. Specifically, SFAs should be widened and there should be policies to intensify antismoking social marketing.

Acknowledgements The authors would like to thank Sugiharso Safuan, Jossy P Moeis, Turro S Wongkaren, Sartika Djamaluddin and Wahyu Prasetyawan for their suggestions on the content and analysis in the draft of paper. We would like to thank Nurhadi Wiyono for editing the early draft of manuscript and for initial English editing.

Contributors TD designed the concept, analysed data, wrote and revised the paper. NDN, AA and DM finalised concept, revised and confirmed the result. All authors read and approved the final manuscript.

Funding This work was supported by Publikasi Internasional Terindeks Mahasiswa Doktor (PITMA A) Universitas Indonesia grant number NKB-0816/UN2.R3.1/ HKP.05.00/2019). The funder had no role in the study design; in the collection, analysis and interpretation of the data; in the writing of the report and in the decision to submit the article for publication. The researchers are independent from the funder.

Competing interests None declared.

Patient consent for publication Not required.

Provenance and peer review Not commissioned; externally peer reviewed.

Data availability statement Data are available upon reasonable request. Data may be obtained from a third party and are not publicly available. Two data sets (SUSENAS and PODES) can be accessed through www.silastik.bps.go.id with permission from Central Bureau of Statistics. Others are published data (references number 14 and 15)

Supplemental material This content has been supplied by the author(s). It has not been vetted by BMJ Publishing Group Limited (BMJ) and may not have been peer-reviewed. Any opinions or recommendations discussed are solely those of the author(s) and are not endorsed by BMJ. BMJ disclaims all liability and responsibility arising from any reliance placed on the content. Where the content includes any translated material, BMJ does not warrant the accuracy and reliability of the translations (including but not limited to local regulations, clinical guidelines, terminology, drug names and drug dosages), and is not responsible for any error and/or omissions arising from translation and adaptation or otherwise.

Open access This is an open access article distributed in accordance with the Creative Commons Attribution Non Commercial (CC BY-NC 4.0) license, which permits others to distribute, remix, adapt, build upon this work non-commercially, and license their derivative works on different terms, provided the original work is properly cited, appropriate credit is given, any changes made indicated, and the use is non-commercial. See: http://creativecommons.org/licenses/by-nc/4.0/.
ORCID iD

Triasih Djutaharta http://orcid.org/0000-0001-5912-2860

\section{REFERENCES}

1 De BJ, Yurekli AA. Curbing the tobacco epidemic in Indonesia. Watch $\mathrm{Br}$ 2000;6:1-9.

2 Tan Y, Dorotheo U. The Tobacco Control Atlas: ASEAN Region. In: Ritthiphakdee B, Kolandai MA, Villarreiz D, et al, eds. Southeast Asia tobacco control alliance (SEATCA. Third Edit. Bangkok: Southeast Asia Tobacco Control Alliance (SEATCA), 2016.

3 Tan Y, Dorotheo U. The Tobacco Atlas: ASEAN Region. In: Ritthiphakdee B, Kolandai MA, Villarreiz D, et al, eds. Fourth Edi. Bangkok: Southeast Asia Tobacco Control Alliance (SEATCA), 2018.

4 Sunley EM, Yurekli A, Chaloupka FJ. The Design, Administration, and Potential Revenue of Tobacco Excises. In: Jha P, Chaloupka FJ, eds. Tobacco control in developing countries. Oxford University Press, 2000: 409-26.

5 IARC. Effectiveness of Tax and price policies for tobacco control. vol. 14. Lyon, France: Handbook on Tobacco Control, 2011.

6 Marquez P V, Moreno-Dodson B. At the crossroads of health and development a Multisectoral perspective. Washington: World Bank Group, 2017.

7 Djutaharta T, Surya HV, Pasay NH. Aggregate Analysis of the Impact of Cigarette Tax Rate Increases on Tobacco Consumption and Government Revenue : The Case of Indonesia. Vol. 25, HNP Discussion Paper: Economics of Tobacco Control Paper. Washington 2005.

8 Adioetomo SM, Djutaharta T, Consumption HC. Taxation, and Household Income : Indonesia Case Study. Vol. 26, HNP Discussion Paper: Economics of Tobacco Control Paper. Washington 2005.

9 Hidayat B, Thabrany H. Cigarette smoking in Indonesia: examination of a myopic model of addictive behaviour. Int J Environ Res Public Health 2010;7:2473-85.

$10 \mathrm{Ng} \mathrm{N}$, Weinehall L, Öhman A. 'If I don't smoke, I'm not a real man'-Indonesian teenage boys' views about smoking. Health Educ Res 2007;22:794-804.

11 Nichter M, Padmawati S, Danardono M, et al. Reading culture from tobacco advertisements in Indonesia. Tob Control 2009;18:98-107.

12 Tandilittin H, Luetge C. Civil Society and tobacco control in Indonesia: the last resort. TOJ 2013;7:11-18.

13 Smet B, Maes L, De Clercq L, et al. Determinants of smoking behaviour among adolescents in Semarang, Indonesia. Tob Control 1999;8:186-91.

$14 \mathrm{MOH}$ B. Indeks Pembangunan Kesehatan Masyarakat [Index of Community Health Development]. In: Suwandono A, ed. Balitbangkes. 2nd ed. Jakarta: Badan Penelitian dan Pengembangan Kesehatan, 2013.

15 B, TCSC-IAKMI MOH. Bunga Rampai Fakta Tembakau dan Permasalahannya [Tobacco Fact and Problem] 2014;V. Vol..

16 Statistik BP. Statistik Potensi Desa Indonesia NVillage Potential Statistics of Indonesia] 2014. Jakarta: BPS, 2014: 1-190.

17 Deaton A, Muellbauer J. An almost ideal demand system. Am Econ Rev 1980;70:312-26.

18 Ray R. Measuring the costs of children: an alternative approach. $J$ Public Econ 1983;22:89-102.

19 Pollak RA. Interdependence preference. Am Econ Assoc 1976;66:1.

20 Alessie R, Kapteyn A, Formation H. Habit formation, interdependent preferences and demographic effects in the almost ideal demand system. The Economic Journal 1991;101:404-19.

21 Heckman JJ. Sample selection bias as a specification error. Econometrica 1979;47:153-61.

22 Johar M, Soewondo P, Pujisubekti R, et al. In data we trust? an analysis of Indonesian socioeconomic survey data. Bull Indones Econ Stud 2019;55:61-82.

23 Abrianty T S. Why Decentralization in Indonesia is Not Good for Reducing Women Fertility ? Results from National Socio Economic Survey 2002-2014 and A Case Study. J Public Adm Stud 2017;1:44-63.

24 Midayanti N. Do neighbours matter? household welfare and social interactions effects: evidence in Indonesia. graduate program in economics. Universitas Indonesia, 2017.

25 Yamamura E. The effects of the social norm on cigarette consumption: evidence from Japan using panel data. Japan World Econ 2011;23:6-12.

26 Widarjono A. Food and nutrient demand in Indonesia. Oklahoma State University, 2012.

27 Ecker O, Qaim M. Analyzing nutritional impacts of policies: an empirical study for Malawi. World Dev 2011;39:412-28. 
28 Moeis JP. Indonesian food demand system: an analysis of the impact of the economic crisis on household consumption and nutritional intake. The George Washington University, 2003.

29 Huang KS. Nutrient Elasticities in a complete food demand system. Am J Agric Econ 1996;78:21-9.

30 Hawkins SS, Kull M, Baum CF. US state cigarette Tax increases and smoke-free legislation in relation to cigarette expenditure across household socio-economic circumstances: a quasi-experimental study. Addiction 2019;114:721-9.

31 Husain MJ, Virk-Baker M, Parascandola M, et al. Money gone up in smoke: the tobacco use and malnutrition nexus in Bangladesh. Ann Glob Health 2016;82:e1:749-59.

32 Balitbangkes Minister of Health, TCSC-IAKMI. Riset Kesehatan Dasar [Basic Health Research. Jakarta, 2013.

33 Tim Riskesdas. Laporan Nasional Riskesdas [Report on National Riskesdas] 2018. Jakarta, 2019.

34 Aristei D, Pieroni L, Addiction PL. Addiction, social interactions and gender differences in cigarette consumption. Empirica 2009;36:245-72.
35 Alamar B, Glantz SA. Effect of increased social unacceptability of cigarette smoking on reduction in cigarette consumption. Am J Public Health 2006;96:1359-63.

36 Poutvaara P, Siemers L-HR. Smoking and social interaction. J Health Econ 2008;27:1503-15.

37 Ratnawaty L, Hartini S. Pelaksanaan Peraturan Daerah Nomor 12 Tahun 2009 Tentang Kawasan Tanpa Rokok di Kota Bogor [Implementation of Regulation No 122009 on Smoke Free Area in Bogor City]. Yustisi 2017;4:68-74

38 Azkha N. Studi Efektivitas Penerapan Kebijakan Perda Kota Tentang Kawasan Tanpa Rokok (KTR) Dalam Upaya Menurunkan Perokok Aktif Di Sumatera Barat Tahun [Effectivity Study on Smoke Free Area Policy in Effort to Reduce Number of Active Smoker in West Sumatera] 20. J Kebijak Kesehat Indones 2013;02:171-9.

39 Wahyuti W, Hasairin S, Mamoribo S, et al. Monitoring compliance and examining challenges of a smoke-free policy in Jayapura, Indonesia. J Prev Med Public Health 2019;52:427-32. 